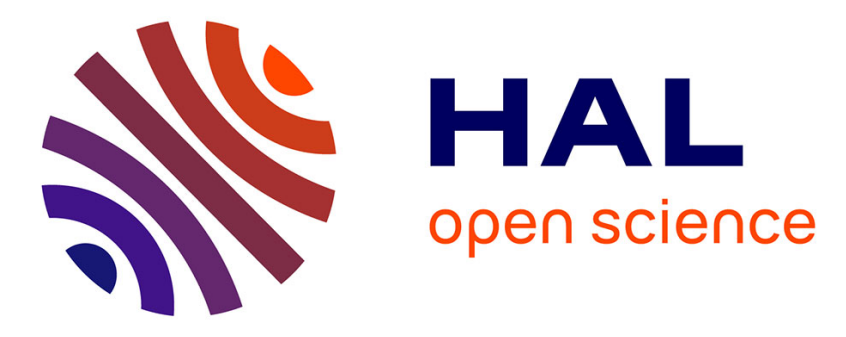

\title{
Linearity and robustness evaluation of 150-nm AlN/GaN HEMTs
}

Mehdi Rzin, Matteo Meneghini, Fabiana Rampazzo, V Gao Zhan, Carlo de Santi, Riad Kabouche, Malek Zegaoui, F Medjdoub, Gaudenzio Meneghesso, Enrico Zanoni

\section{To cite this version:}

Mehdi Rzin, Matteo Meneghini, Fabiana Rampazzo, V Gao Zhan, Carlo de Santi, et al.. Linearity and robustness evaluation of 150-nm AlN/GaN HEMTs. Microelectronics Reliability, 2019, 100-101, pp.113388. 10.1016/j.microrel.2019.06.080 . hal-02356749

\section{HAL Id: hal-02356749 \\ https://hal.science/hal-02356749}

Submitted on 8 Dec 2020

HAL is a multi-disciplinary open access archive for the deposit and dissemination of scientific research documents, whether they are published or not. The documents may come from teaching and research institutions in France or abroad, or from public or private research centers.
L'archive ouverte pluridisciplinaire $\mathbf{H A L}$, est destinée au dépôt et à la diffusion de documents scientifiques de niveau recherche, publiés ou non, émanant des établissements d'enseignement et de recherche français ou étrangers, des laboratoires publics ou privés. 


\title{
Linearity and robustness evaluation of 150-nm AlN/GaN HEMTs
}

\author{
M. Rzinª,*, M. Meneghinia, F. Rampazzo ${ }^{\text {a }}$, V. Gao Zhan ${ }^{\mathrm{a}}$, C. De Santia, R. \\ Kabouche $^{\mathrm{b}}$, M. Zegaoui ${ }^{\mathrm{b}}$, F. Medjdoub ${ }^{\mathrm{b}}$, G. Meneghesso ${ }^{\mathrm{a}}$, E. Zanoni ${ }^{\mathrm{a}}$ \\ a Department of information engineering, University of Padova, via Gradenigo 6/B, 35131 Padova, Italy \\ ${ }^{b}$ IEMN - CNRS, Institute of Electronics, Microelectronics and Nanotechnology, UMR8520 Av. Poincaré, 59650 \\ Villeneuve d'Ascq, France
}

\begin{abstract}
We report on linearity and robustness of AlN/GaN HEMTs with ultra-thin 4nm AlN barrier for millimeter wave range applications. Static and dynamic I-V characteristics feature high peak transconductance $\left(\mathrm{g}_{\text {mpeak }}\right)$ of $385 \mathrm{mS} / \mathrm{mm}$, and the transconductance exhibits small changes with gate bias. Semi on-state step stress and $24 \mathrm{~h}$ stress tests have been carried out on representative AIN/GaN HEMTs on SiC substrate. No catastrophic failure was identified after semi on-state step stress at $\mathrm{V}_{\mathrm{GS}}=-1.5 \mathrm{~V}$ up to $\mathrm{V}_{\mathrm{DS}}=100 \mathrm{~V}$, whereas a gmpeak drop of $26 \%$ was observed in these conditions. Moreover, $24 \mathrm{~h}$ stress carried out at different bias voltage along a load line show good robustness of these devices up to $\mathrm{V}_{\mathrm{DS}}=25 \mathrm{~V}$. In addition, an abrupt gate leakage current increase was identified to be field dependent, and associated with hot spots identified by electroluminescence measurements. Even in presence of a simple SiN passivation without air bridges or field plates, these devices exhibit high power added efficiency up to $40 \mathrm{GHz}$, thus demonstrating the great potential of AlN/GaN heterostructures.
\end{abstract}

\section{Introduction}

GaN based High Electron Mobility Transistors (HEMTs) hold tremendous interest for millimeter wave applications especially with the emergence of the fifth generation $(5 \mathrm{G})$ communications technology, this is thanks to their high electron mobility and breakdown voltage [1]. For high power amplifiers (HPA) operating beyond $30 \mathrm{GHz}$, innovative device downscaling with ultra-short gate length $\left(\mathrm{L}_{\mathrm{G}}<200 \mathrm{~nm}\right)$ and ultra-thin barrier layer are needed whilst maintaining high power added efficiency (PAE) combined with high output power in millimeter wave range. Recently, AlN/GaN HEMTs with sub-10nm AlN barrier layer demonstrated promising performance with PAE exceeding $40 \%$ at $40 \mathrm{GHz}$ [2]. AlN/GaN HEMTs with a maximum output current density of $2.3 \mathrm{~A} / \mathrm{mm}$ and a peak extrinsic transconductance of 480 $\mathrm{mS} / \mathrm{mm}[3]$ have also been reported.

The transconductance of $\mathrm{GaN}$ based HEMTs exhibits significant changes with the gate bias, and this is considered as a critical issue for the linearity performance of the device [4] [5] [6]. This limits large signal operation at high frequencies as well as power linearity, since the gain of a HEMT is critically dependent on the transconductance. The devices used in multichannel transmissions tend to produce intermodulation distortion, which leads to the degradation of the system signal-to-noise ratio. The third-order intermodulation distortion (IM3) is considered as the most important parameter for the linearity performance of the devices. In order to reduce IM3, the transconductance needs to remain constant during a wide operating range of the gate bias [7].

In this paper, we evaluate the linearity and robustness of $150-\mathrm{nm}$ AlN/GaN HEMTs on SiC substrate with C-doped GaN buffer and 4-nm AlN barrier. In addition to their outstanding RF performance in terms of high output power combined with high power added efficiency at 40 GHz, AlN/GaN HEMTs show good robustness after 24 hours stress test.

\section{Samples details}

The AlN/GaN heterostructures were grown by metal organic chemical vapor deposition (MOCVD) on 4 inch $\mathrm{SiC}$ substrates [8]. The HEMT structure consists of transition layers to $\mathrm{GaN}$, a $1 \mu \mathrm{m}$-thick Cdoped GaN buffer layer followed by an undoped GaN channel, a $4.0 \mathrm{~nm}$ ultrathin AlN barrier layer and a 10 -nm-thick in situ $\mathrm{Si}_{3} \mathrm{~N}_{4}$ cap layer. The in-situ $\mathrm{SiN}$ layer is used both as early passivation as well as to prevent strain relaxation. Room-temperature Hall measurements showed high electron sheet

\footnotetext{
* Corresponding author. ab.dupont@univ.tlse.fr Tel: +33 (056) 1336000 ; Fax: +33 (056) 1336200
} 
concentrations of $1.8 \times 10^{13}$ and $1.6 \times 10^{13} \mathrm{~cm}^{-2}$ with an electron mobility about $1100 \mathrm{~cm}^{2} \mathrm{~V}^{-1} \mathrm{~s}^{-1}$.

\section{DC and double pulse characterization}

Erreur ! Source du renvoi introuvable. shows transconductance $\left(\mathrm{g}_{\mathrm{m}}\right)$ versus $\mathrm{V}_{\mathrm{GS}}$ characteristics of a representative AlN/GaN HEMT. The extrinsic transconductance peaks at $385 \mathrm{mS} / \mathrm{mm}$ at $\mathrm{V}_{\mathrm{DS}}=10$ $\mathrm{V}$ and $\mathrm{V}_{\mathrm{GS}}=-1.3 \mathrm{~V}$. This high value results from the short gate-to-channel distance [9].

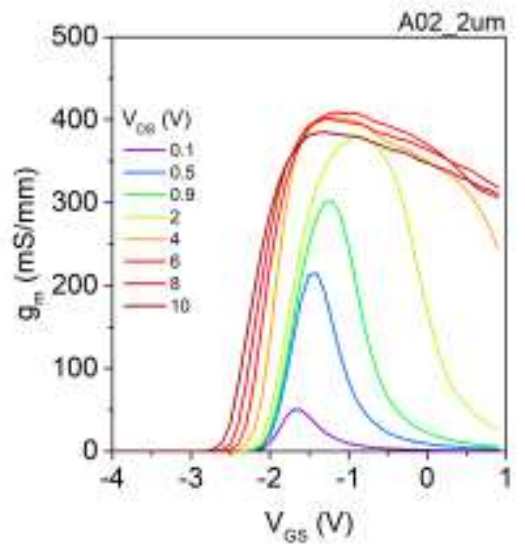

Fig - 1. $g_{m}$ versus $V_{G S}$ characteristics of a representative AlN/GaN HEMT

Interestingly, the transconductance of AlN/GaN HEMTs exhibits small changes with the gate bias for $\mathrm{V}_{\mathrm{DS}}>4 \mathrm{~V}$, unlike for $\mathrm{AlGaN} / \mathrm{GaN}$ HEMTs. This is owing to the ultra-thin AIN barrier with high $\mathrm{Al}$ content, and to the less negative threshold voltage [10][11] . Fig - 2 shows the double pulse $g_{m}$ versus $V_{G S}$ characteristics at $\mathrm{V}_{\mathrm{DS}}=8 \mathrm{~V}$ at quiescent bias $(\mathrm{QB})$ conditions $(0 \mathrm{~V}$, $0 \mathrm{~V}),(-5 \mathrm{~V}, 0 \mathrm{~V}),(-5 \mathrm{~V}, 5 \mathrm{~V})$ and $(-5 \mathrm{~V}, 10 \mathrm{~V})$ of a representative AIN/GaN HEMT. The pulse width was set to $1 \mu \mathrm{s}$ with a duty cycle of $1 \%$. The current collapse rate corresponding to the gate-lag is $16.5 \%$. Moreover, the drain lag rate between ( -5 $\mathrm{V}, 0 \mathrm{~V})$ and $(-5 \mathrm{~V}, 10 \mathrm{~V})$ corresponds to $13.3 \%$.

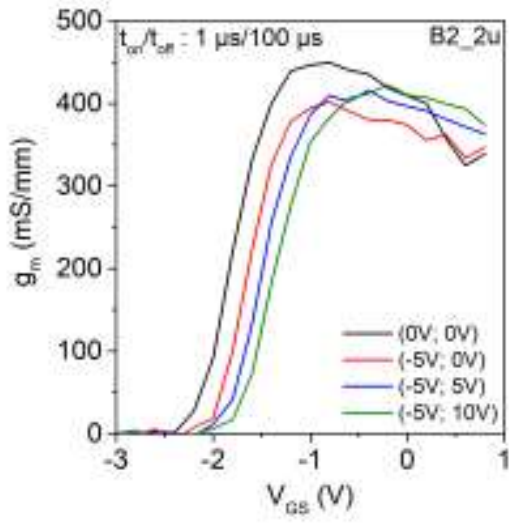

Fig - 2. Double pulse $\mathrm{g}_{\mathrm{m}}-\mathrm{V}_{\mathrm{GS}}$ characteristics at different QB conditions of a representative AlN/GaN HEMT.

A positive shift of threshold voltage, that is correlated with current collapse, is identified at QB $(-5 \mathrm{~V}, 0 \mathrm{~V})$ that increases by increasing drain source $\mathrm{QB}$. Moreover, the transconductance versus $\mathrm{V}_{\mathrm{GS}}$ remains high at positive $\mathrm{V}_{\mathrm{GS}}$ under the different $\mathrm{QB}$ conditions

\section{Semi on-state step stress}

Before starting short or long term reliability tests at the bias targeted for the final application for these devices (in this case high power amplifiers (HPA) in class $\mathrm{AB}$ operation), it is mandatory to evaluate the limits and the safe operating area (SOA) of the process. DC step stress test is submitted at semi onstate $\left(\mathrm{V}_{\mathrm{GS}}>\mathrm{V}_{\mathrm{TH}}\right)$ condition. For this bias point, the gate is biased at $\mathrm{V}_{\mathrm{GStress}}=-1.5 \mathrm{~V}$ and the drain voltage is increased from $0 \mathrm{~V}$ to device failure by a step of $5 \mathrm{~V}$ during 2 min each step [12]. In this case, the drain voltage compliance was limited to $100 \mathrm{~V}$. During the step stress test, drain and gate currents are monitored, electroluminescence is used after each step in on-state (peak of EL bell versus $V_{\mathrm{GS}}$ ) and offstate conditions, to check the distribution of the electroluminescence emission on the gate fingers during stress, if there are hot spots induced by the stress showing the creation of leakage paths or for the onset of the device failure. Fig - 3 shows $g_{m}-V_{G S}$ characteristics, at $\mathrm{V}_{\mathrm{DS}}=0.1$ and $10 \mathrm{~V}$, after each step of semi on-state step stress at $\mathrm{V}_{\mathrm{GStress}}=-1.5 \mathrm{~V}$. As illustrated in Fig - 4, the transconductance peak as well as the threshold voltage remain constant until $\mathrm{V}_{\text {DStress }}=25 \mathrm{~V}$. Moreover, $\mathrm{g}_{\text {mpeak }}$ decreases almost linearly for $\mathrm{V}_{\text {DStress }}>25 \mathrm{~V}$ to drop by $26 \%$ at $\mathrm{V}_{\text {DStress }}$ $=100 \mathrm{~V}$. Furthermore, the threshold voltage shifts positively for $\mathrm{V}_{\text {DStress }}>25 \mathrm{~V}$ to shift by $46 \mathrm{mV}$ at $\mathrm{V}_{\text {DStress }}=100 \mathrm{~V}$. Moreover, an abrupt decrease of forward and reverse gate voltage, in addition to an increase of gate leakage current are identified at $\mathrm{V}_{\mathrm{DS}}>25 \mathrm{~V}$ as shown in Fig -5. 


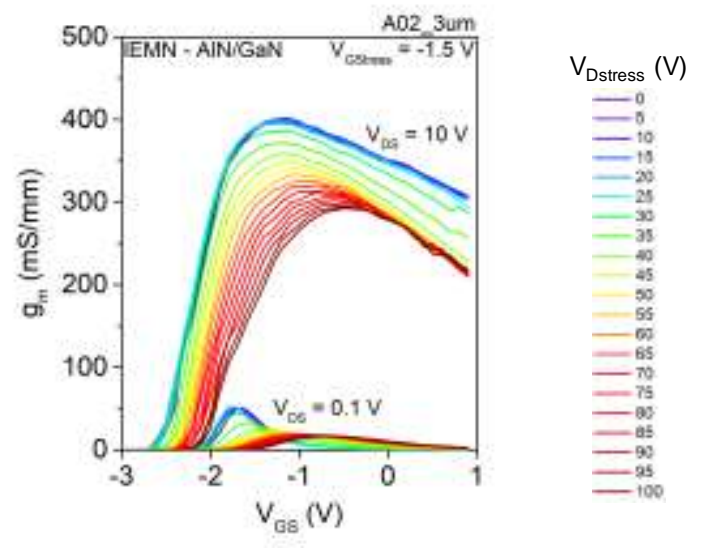

Fig $-3 . \mathrm{g}_{\mathrm{m}}-\mathrm{V}_{\mathrm{GS}}$ characteristics after each of semi onstate step stress at $\mathrm{V}_{\mathrm{GStress}}=-1.5 \mathrm{~V}$

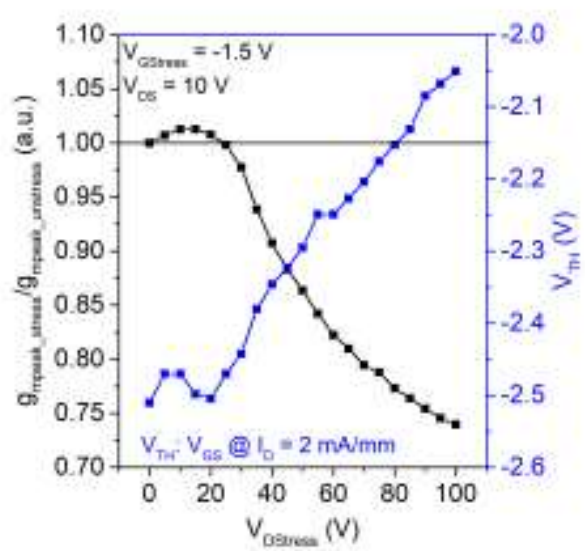

Fig - 4. $\mathrm{G}_{\mathrm{mpeak}}$ and $\mathrm{V}_{\mathrm{TH}}$ at $\mathrm{V}_{\mathrm{DS}}=10 \mathrm{~V}$ variation during semi on-state step stress at $\mathrm{V}_{\mathrm{GStress}}=-1.5 \mathrm{~V}$ of AlN/GaN HEMT

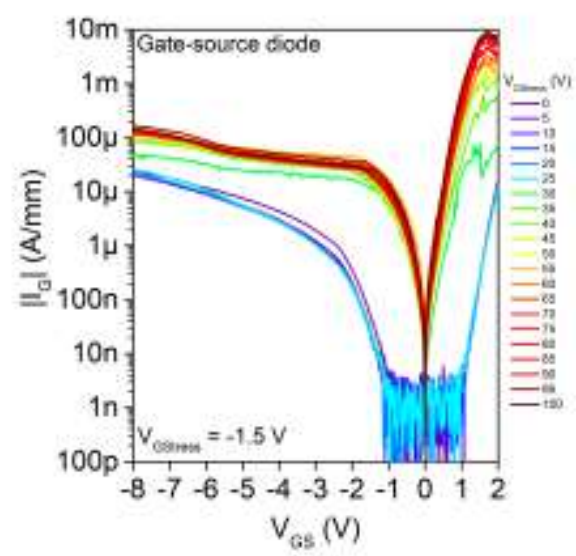

Fig - 5. $I_{G}-V_{G}$ characteristics after each step of semi on-state step stress at $\mathrm{V}_{\mathrm{GStress}}=-1.5 \mathrm{~V}$ of AIN/GaN HEMT

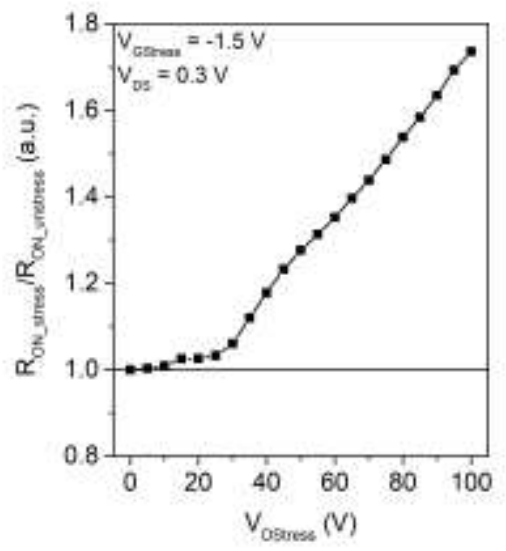

Fig - 6. RoN variation during semi on-state step stress at $\mathrm{V}_{\mathrm{GStress}}=-1.5 \mathrm{~V}$ of $\mathrm{AlN} / \mathrm{GaN}$ HEMT

The on-state resistance $\left(\mathrm{R}_{\mathrm{ON}}\right)$ shows no degradation up to $\mathrm{V}_{\mathrm{DS}}=25 \mathrm{~V}$, whereas it linearly increases for $\mathrm{V}_{\mathrm{DS}}>25 \mathrm{~V}$ to degrade by about $74 \%$ at $\mathrm{V}_{\mathrm{DS}}=100 \mathrm{~V}$, as shown in Fig - 6. By considering the different parameters variation with semi on-state step stress, it is suggested that the non-reversible degradation occurs at the critical voltage $V_{D S}=25 \mathrm{~V}$, due to degradation in the access regions ( $\mathrm{R}_{\mathrm{ON}}$ variation) and below the gate contact ( $\mathrm{V}_{\mathrm{TH}}$ variation) to be related to degradation of Schottky/AlN and SiN/AlN interfaces that field driven.

\section{DC 24h robustness stress}

This part focuses on the robustness of AlN/GaN HEMTs, by using 24 hours DC stress test, to assess the root cause for degradation mechanisms under stress limiting the electrical performance by considering semi on-state condition with $\mathrm{V}_{\text {DStress }} \leq 25 \mathrm{~V}$. In this part, we discuss the robustness of AlN/GaN HEMTs at the bias conditions: ( $\mathrm{V}_{\mathrm{GStress}}$, $\left.\mathrm{V}_{\text {DStress }}\right)=(-1.2 \mathrm{~V}, 10 \mathrm{~V}),(-1.5 \mathrm{~V}, 15 \mathrm{~V}) .(-2 \mathrm{~V}, 20$ $\mathrm{V})$ and $(-2.5 \mathrm{~V}, 25 \mathrm{~V})$. Different electrical parameters are recorded after interrupting the stress at $1 \mathrm{~h}, 2 \mathrm{~h}, 4 \mathrm{~h}, 8 \mathrm{~h}, 16 \mathrm{~h}$ and $24 \mathrm{~h}$. Fig - 7 illustrates $\mathrm{I}_{\mathrm{D}^{-}}$ $\mathrm{V}_{\mathrm{DS}}$ characteristics of a representative AlN/GaN HEMT with $\mathrm{V}_{\mathrm{GS}}$ from $-3 \mathrm{~V}$ to $0 \mathrm{~V}$ with a pronounced kink effect. Circular dots are $\mathrm{I}_{\mathrm{D}}-\mathrm{V}_{\mathrm{DS}}$ bias-points adopted for 24-hours tests. 


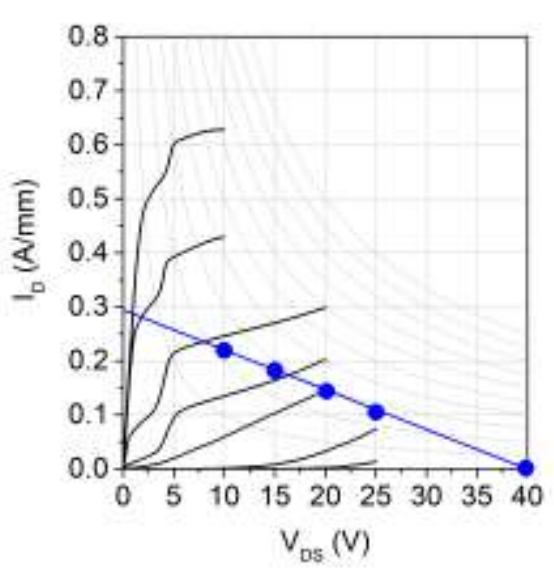

Fig - 7. ID vs VDS output characteristics of representative AlN/GaN HEMT, with VGs from $-3 \mathrm{~V}$ to $+1 \mathrm{~V}$ in $0.5 \mathrm{~V}$ steps. Circular dots are ID-VDS bias-points adopted for 24-hours tests

\section{1. $\left(V_{G S t r e s s} ; V_{D S t r e s s}\right)=(-1.2 \mathrm{~V}, 10 \mathrm{~V})$}

Fig - 8 shows the variation of gate current during $24 \mathrm{~h}$ stress test at different steps: 1h, 2h, 4h, 8h, 16h and $24 \mathrm{~h}$, carried out at $\left(\mathrm{V}_{\mathrm{GStress}}, \mathrm{V}_{\mathrm{DStress}}\right)=(-1.2 \mathrm{~V}$, $10 \mathrm{~V})$. Although the gate current is slightly noisy during the stress, it remains stable at a steady level around $1 \mu \mathrm{A} / \mathrm{mm}$.

Moreover, electroluminescence (EL) emission intensity is uniformly distributed along the gate fingers during the stress, highlighting the good distribution of carriers in the channel, as shown in Fig - 9. Moreover, no hot spots are identified during stress. The microscopy image of the stressed device after $24 \mathrm{~h}$ stress shows no damage in the device structure.

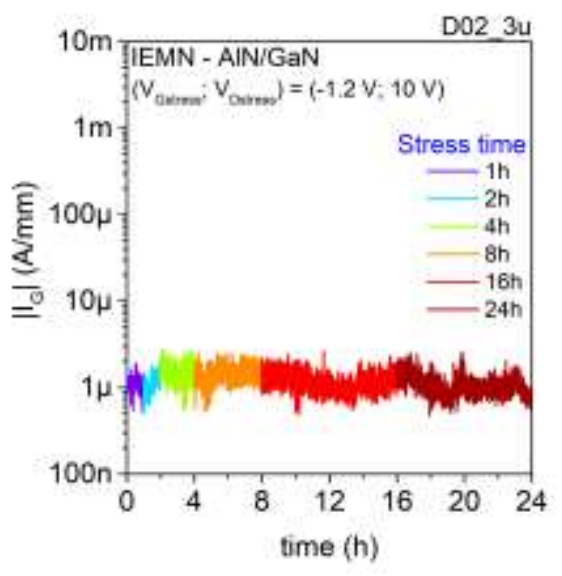

Fig - 8. Variation of gate current during 24h stepstress experiment carried out at ( $\mathrm{V}_{\mathrm{GStress}}, \mathrm{V}_{\mathrm{DS}}$ tress) $=(-1.2 \mathrm{~V}, 10 \mathrm{~V})$ with the electrical parameters monitored at $1 \mathrm{~h}, 2 \mathrm{~h}, 4 \mathrm{~h}, 8 \mathrm{~h}, 16 \mathrm{~h}$ and $24 \mathrm{~h}$ of AlN/GaN HEMT
$1 \mathrm{~h}$
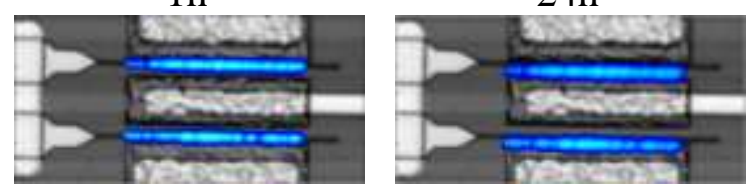

Fig - 9. Electroluminescence emission microscopy images during $24 \mathrm{~h}$ stress test at two steps: $1 \mathrm{~h}$ and $24 \mathrm{~h}$ at $\left(\mathrm{V}_{\mathrm{GStress}}, \mathrm{V}_{\mathrm{DStress}}\right)=(-1.2 \mathrm{~V}, 10 \mathrm{~V})$ of AlN/GaN HEMT.

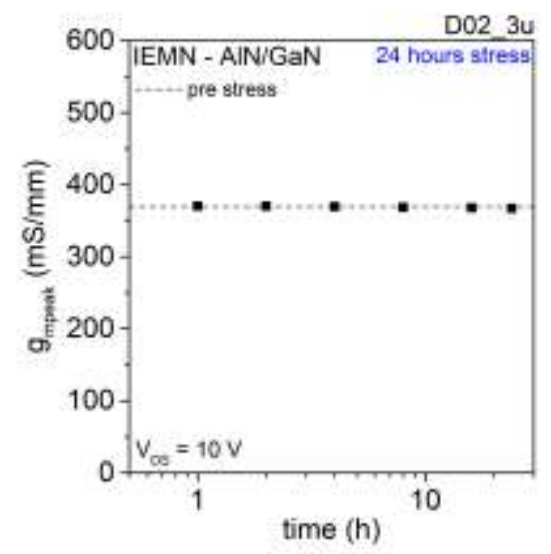

Fig - 10. gmpeak $_{\text {at }} \mathrm{V}_{\mathrm{DS}}=10 \mathrm{~V}$ monitoring during $24 \mathrm{~h}$ stress carried out at $\left(\mathrm{V}_{\mathrm{GStress}}, \mathrm{V}_{\mathrm{DStress}}\right)=(-1.2 \mathrm{~V}$, $10 \mathrm{~V}$ ) of $\mathrm{AlN} / \mathrm{GaN}$ HEMT

Fig - 10 shows $g_{\text {mpeak }}$ at $\mathrm{V}_{\mathrm{DS}}=10 \mathrm{~V}$ monitored during the different steps of the $24 \mathrm{~h}$ stress at $\left(\mathrm{V}_{\mathrm{GStress}}\right.$ , $\left.\mathrm{V}_{\text {DStress }}\right)=(-1.2 \mathrm{~V}, 10 \mathrm{~V})$ compared to their initial values before stress. The $\mathrm{g}_{\text {mpeak }}$ values after the different steps of the $24 \mathrm{~h}$ stress are superimposed with their initial values before stress.

Thus, no abrupt leakage currents increase or device degradation are identified after $24 \mathrm{~h}$ stress at $\left(\mathrm{V}_{\mathrm{GStress}}, \mathrm{V}_{\mathrm{DStress}}\right)=(-1.2 \mathrm{~V}, 10 \mathrm{~V})$.

\section{2. $\left(V_{G S t r e s s} ; V_{D S t r e s s}\right)=(-1.5 \mathrm{~V}, 15 \mathrm{~V})$}

Fig - 11 shows the variation of gate current during $24 \mathrm{~h}$ stress test at different steps: $1 \mathrm{~h}, 2 \mathrm{~h}, 4 \mathrm{~h}$, $8 \mathrm{~h}, 16 \mathrm{~h}$ and $24 \mathrm{~h}$, carried out at $\left(\mathrm{V}_{\mathrm{GStress}}, \mathrm{V}_{\mathrm{DStress}}\right)=(-$ $1.5 \mathrm{~V}, 15 \mathrm{~V}$ ) of AlN/GaN HEMT.

The gate current, during the stress, becomes more noisy starting from $10 \mathrm{~h}$ stress, however it remains stable with no apparent abrupt increase with $\left|\mathrm{I}_{\mathrm{G}}\right| \leq 1 \mu \mathrm{A} / \mathrm{mm}$.

EL intensity after $1 \mathrm{~h}$ and $24 \mathrm{~h}$ stress at $\left(\mathrm{V}_{\mathrm{GStress}}\right.$, $\left.\mathrm{V}_{\text {DStress }}\right)=(-1.5 \mathrm{~V}, 15 \mathrm{~V})$ is higher on the edge of gate fingers, as shown in Fig - 12. Furthermore, $\mathrm{g}_{\text {mpeak }}$ values after the different steps of the $24 \mathrm{~h}$ stress are lower by less than $5 \%$ with their initial values before stress as illustrated in Fig - 13. 


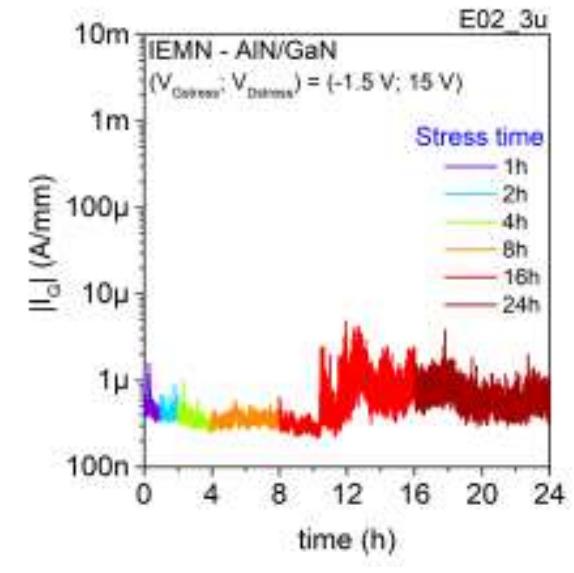

Fig - 11. Variation of gate current during 24h stepstress experiment carried out at $\left(\mathrm{V}_{\mathrm{GStress}}, \mathrm{V}_{\mathrm{DStress}}\right)$ $=(-1.5 \mathrm{~V}, 15 \mathrm{~V})$ with the electrical parameters monitored at $1 \mathrm{~h}, 2 \mathrm{~h}, 4 \mathrm{~h}, 8 \mathrm{~h}, 16 \mathrm{~h}$ and $24 \mathrm{~h}$ of AlN/GaN HEMT

$1 \mathrm{~h}$
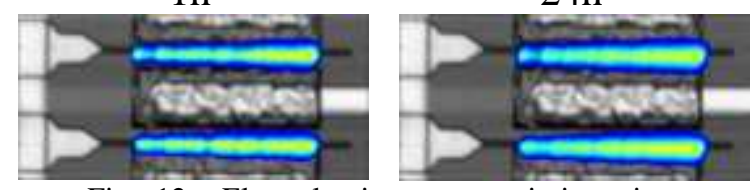

Fig - 12. Electroluminescence emission microscopy images during $24 \mathrm{~h}$ stress test at two steps: $1 \mathrm{~h}$ and $24 \mathrm{~h}$ at $\left(\mathrm{V}_{\mathrm{GStress}}, \mathrm{V}_{\text {DStress }}\right)=(-1.5 \mathrm{~V}, 15 \mathrm{~V})$ of AlN/GaN HEMT.

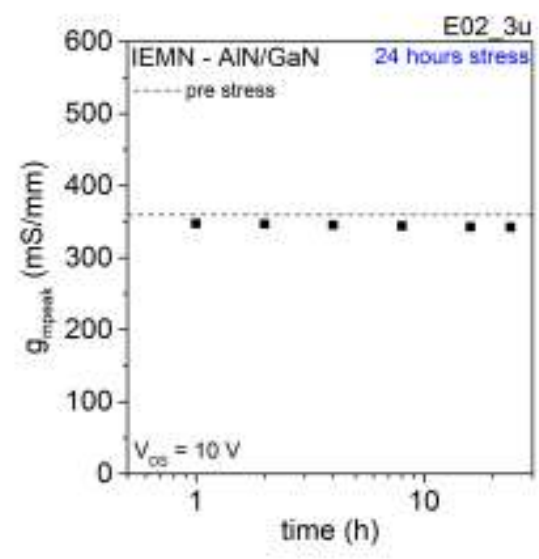

Fig - 13. $\mathrm{g}_{\text {mpeak }}$ at $\mathrm{V}_{\mathrm{DS}}=10 \mathrm{~V}$ monitoring during $24 \mathrm{~h}$ stress carried out at $\left(\mathrm{V}_{\mathrm{GStress}}, \mathrm{V}_{\mathrm{DStress}}\right)=(-1.5 \mathrm{~V}$, $15 \mathrm{~V}$ ) of AlN/GaN HEMT

Thus, no abrupt leakage currents increase or device degradation are identified after $24 \mathrm{~h}$ stress at $\left(\mathrm{V}_{\mathrm{GStress}}, \mathrm{V}_{\text {DStress }}\right)=(-1.5 \mathrm{~V}, 15 \mathrm{~V})$.

\section{3. $\left(V_{G S t r e s s} ; V_{D S t r e s s}\right)=(-2 \mathrm{~V}, 20 \mathrm{~V})$}

Fig - 14 shows gate current variation during $24 \mathrm{~h}$ stress test at different steps: $1 \mathrm{~h}, 2 \mathrm{~h}, 4 \mathrm{~h}, 8 \mathrm{~h}, 16 \mathrm{~h}$ and

$24 \mathrm{~h}$, at $\left(\mathrm{V}_{\mathrm{GStress}}, \mathrm{V}_{\mathrm{DStress}}\right)=(-2 \mathrm{~V}, 20 \mathrm{~V})$.

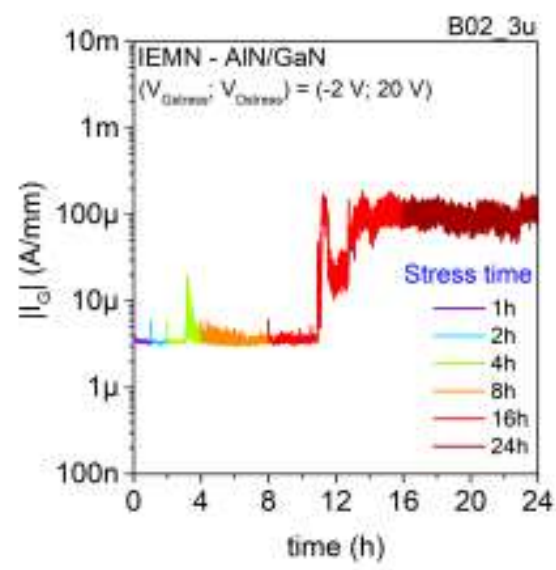

Fig - 14. Variation of gate current during 24h stepstress experiment carried out at ( $\left.\mathrm{V}_{\mathrm{GStress}}, \mathrm{V}_{\mathrm{DStress}}\right)$ $=(-2 \mathrm{~V}, 20 \mathrm{~V})$ with the electrical parameters monitored at $1 \mathrm{~h}, 2 \mathrm{~h}, 4 \mathrm{~h}, 8 \mathrm{~h}, 16 \mathrm{~h}$ and $24 \mathrm{~h}$ of AlN/GaN HEMT

The gate current, during the stress, becomes more noisy starting from $12 \mathrm{~h}$ stress, with an abrupt increase from $4 \mu \mathrm{A} / \mathrm{mm}$ to $100 \mu \mathrm{A} / \mathrm{mm}$. This result suggests that the gate current degradation, during the stress, is field driven. EL intensity is uniform along both gate fingers with some regions where EL intensity is higher after $1 \mathrm{~h}$ stress, as shown in Fig 15 , with EL intensity increasing after $24 \mathrm{~h}$ stress.

$1 \mathrm{~h}$

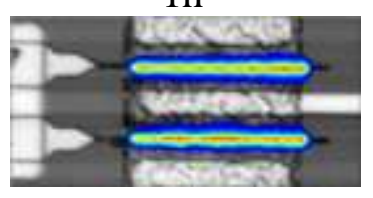

Fig - 15. Electroluminescence emission microscopy images during $24 \mathrm{~h}$ stress test at two steps: $1 \mathrm{~h}$ and $24 \mathrm{~h}$ at $\left(\mathrm{V}_{\mathrm{GStress}}, \mathrm{V}_{\mathrm{DStress}}\right)=(-2 \mathrm{~V}, 20 \mathrm{~V})$ of AlN/GaN HEMT.

Moreover, $g_{\text {mpeak }}$ values monitored after the different steps of the $24 \mathrm{~h}$ stress are superimposed with their initial values before stress as illustrated in Fig - 16 . 


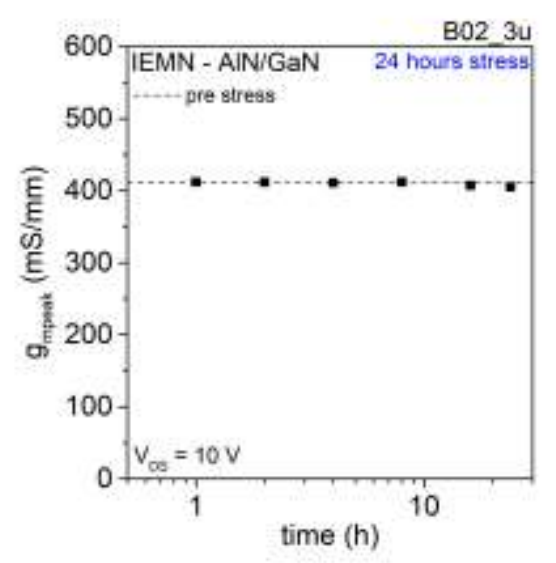

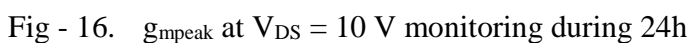
stress carried out at $\left(\mathrm{V}_{\mathrm{GStress}}, \mathrm{V}_{\mathrm{DStress}}\right)=(-2 \mathrm{~V}, 20$ $\mathrm{V})$ of AlN/GaN HEMT

\section{4. $\left(V_{G S t r e s s} ; V_{D S t r e s s}\right)=(-2.5 \mathrm{~V}, 25 \mathrm{~V})$}

Fig - 17 shows the variation of gate current during $24 \mathrm{~h}$ stress test at different steps: $1 \mathrm{~h}, 2 \mathrm{~h}, 4 \mathrm{~h}$, $8 \mathrm{~h}, \quad 16 \mathrm{~h}$ and $24 \mathrm{~h}$, carried out at $\left(\mathrm{V}_{\mathrm{GStress}}, \mathrm{V}_{\mathrm{DStress}}\right)=(-2.5 \mathrm{~V}, 25 \mathrm{~V})$ of $\mathrm{AlN} / \mathrm{GaN}$ HEMT.

The gate current at the early hour of stress is at higher value of $100 \mu \mathrm{A} / \mathrm{mm}$, that keeps increasing during the first 12 hours of stress and stabilizes at about $3 \mathrm{~mA} / \mathrm{mm}$ at the last 12 hours of the stress.

The gate current increase during $24 \mathrm{~h}$ stress is field dependent and associated with EL hot spots along the gate fingers as shown in Fig - 18 .

The monitoring of $\mathrm{g}_{\text {mpeak }}$ during $24 \mathrm{~h}$ stress shows a constant decrease of about $10 \%$ during all the stress, as shown in Fig - 19. The uniform degradation of $\mathrm{g}_{\text {mpeak }}$ is not correlated with gate current increase during stress. The latest is related more likely to Schottky contact degradation and not to the AlN/GaN heterostructure.

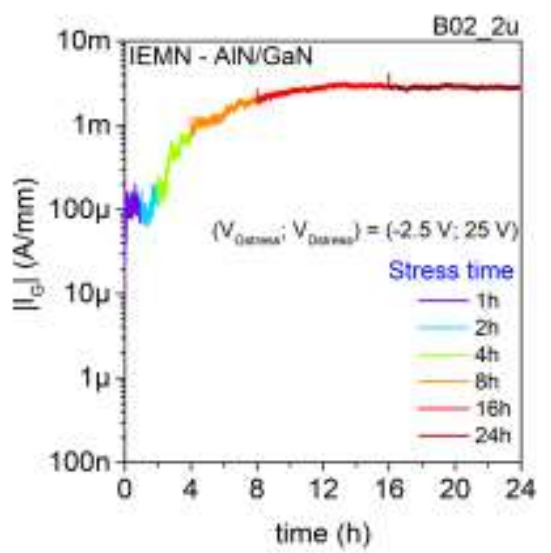

Fig - 17. Variation of gate current during 24h step- stress experiment carried out at ( $\left.\mathrm{V}_{\mathrm{GSStress}}, \mathrm{V}_{\mathrm{DStress}}\right)$ $=(-2.5 \mathrm{~V}, 20 \mathrm{~V})$ with the electrical parameters monitored at $1 \mathrm{~h}, 2 \mathrm{~h}, 4 \mathrm{~h}, 8 \mathrm{~h}, 16 \mathrm{~h}$ and $24 \mathrm{~h}$ of

AlN/GaN HEMT

$1 \mathrm{~h}$

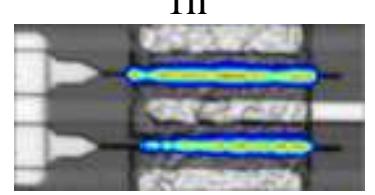

$24 \mathrm{~h}$

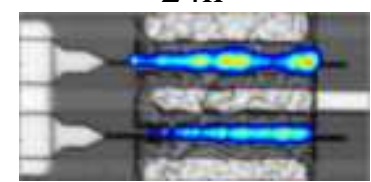

Fig - 18. Electroluminescence emission microscopy images during $24 \mathrm{~h}$ stress test at two steps: $1 \mathrm{~h}$ and $24 \mathrm{~h}$ at $\left(\mathrm{V}_{\mathrm{GStress}}, \mathrm{V}_{\text {DStress }}\right)=(-2.5 \mathrm{~V}, 25 \mathrm{~V})$ of AlN/GaN HEMT.

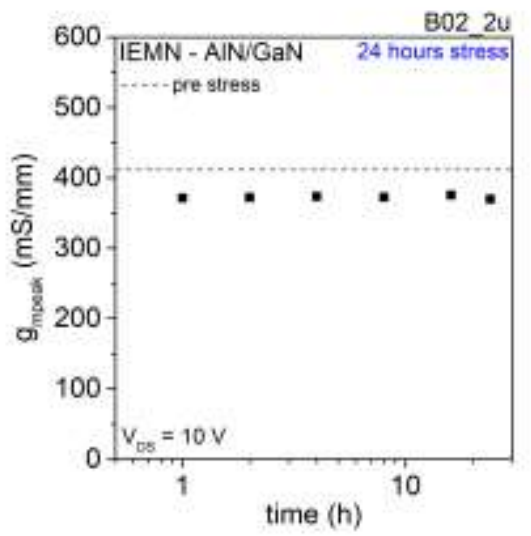

Fig - 19. $\mathrm{g}_{\text {mpeak }}$ at $\mathrm{V}_{\mathrm{DS}}=10 \mathrm{~V}$ monitoring during $24 \mathrm{~h}$ stress carried out at $\left(\mathrm{V}_{\mathrm{GStress}}, \mathrm{V}_{\mathrm{DStress}}\right)=(-2.5 \mathrm{~V}$, $25 \mathrm{~V})$ of AlN/GaN HEMT

\section{Conclusions}

In this work, we have demonstrated the potential of AlN/GaN HEMTs in terms of linearity and robustness under high electric field up to $25 \mathrm{~V}$. The degradation of gate current during stress is field dependent related more likely to degradation of Schottky contact or gate/barrier interface.

In spite of adopting only $\mathrm{SiN}$ passivation without air bridges or field plates, these devices exhibit high power added efficiency above $45 \%$ associated under high output power density up to 40 $\mathrm{GHz}$ demonstrating the potential of $\mathrm{AlN} / \mathrm{GaN}$ heterostructure for millimetre wave applications.

\section{Acknowledgements}

The authors would like to thank the European Defense Agency (EDA) for the support to this work in the context of the project entitled "European Gallium Nitride Industry supply Chain (EUGaNIC)" funded by Germany, France, Italy and Sweden and coordinated by UMS GmbH in the frame of the Project no B-1447-IAP1-GP of the European 
Defense Agency.

\section{References}

[1] K. Yuk, G.R. Branner, C. Cui, "Future Directions for GaN in 5G and Satellite Communications" IEEE 60th International Midwest Symposium on Circuits and Systems (MWSCAS), vol. 803 (2017)

[2] "High PAE high reliability AlN/GaN double heterostructure" Solid-State Electronics 113 (2015) 49-53

[3] "AlN/GaN Insulated-Gate HEMTs with $2.3 \mathrm{~A} / \mathrm{mm}$ output current and $480 \mathrm{mS} / \mathrm{mm}$ transconductance" IEEE Electron Device Letters, Vol. 29, No. 7, July 2008.

[4] J. Vidkjær, S.A. Shevchenko, J. Würfl, M. J. Uren K. Hirche, R. Jost "Linearity Assessment of GaN Technology"

[5] "Influence of the Dynamic Access Resistance in the gm and fT Linearity of AlGaN/GaN HEMTs" IEEE TRANSACTIONS ON ELECTRON DEVICES, VOL. 52, NO. 10, OCTOBER 2005

[6] "Improving the Linearity of GaN HEMTs by Optimizing Epitaxial Structure" IEEE TRANSACTIONS ON ELECTRON DEVICES, VOL. 56, NO. 3, MARCH 2009

[7] “A $\delta$-Doped InGaP/InGaAs pHEMT With Different Doping Profiles for Device-Linearity Improvement" IEEE TRANSACTIONS ON ELECTRON DEVICES, VOL. 54, NO. 7, JULY 2007

[8] "Comparison of C-Doped AlN/GaN HEMTs and AlN/GaN/AlGaN Double Heterostructure for $\mathrm{mmW}$ Applications" Proc. of EUMiC 2018

[9] "High-Performance Low-Leakage-Current AlN/GaN HEMTs Grown on Silicon Substrate" IEEE ELECTRON DEVICE LETTERS, VOL. 32, NO. 7, JULY 2011

[10] "Low interface state density AIN/GaN MISFETs" Electron.Lett. https://doi.org/10.1049/el:19991407 35, 2145 (1999).

[11] "High-mobility window for two-dimensional electron gases at ultrathin $\mathrm{AlN} / \mathrm{GaN}$ heterojunctions" APPLIED PHYSICS LETTERS 90, 182112 (2007)

[12] "Reliability of GaN High-Electron-Mobility Transistors: State of the Art and Perspectives" IEEE TRANSACTIONS ON DEVICE AND MATERIALS RELIABILITY, VOL. 8, NO. 2, JUNE 2008 